\title{
Attitude Towards the Career Building in Journalism Among the Female Students of Communication
}

\author{
Moyna Akter* \\ Independent Researcher \\ Department of Mass Communication and Journalism, Begum Rokeya University, Rangpur-5400 \\ Tabiur Rahman Prodhan \\ Assistant Professor \\ Department of Mass Communication and Journalism, Begum Rokeya University, Rangpur-5400 \\ Razu Ahmmed \\ Independent Researcher \\ Department of Mass Communication and Journalism, Begum Rokeya University, Rangpur-5400
}

\begin{abstract}
This research work looked at female students' attitudes toward Mass Communication and journalism to build a journalism career. This study's objectives were to determine female mass communication students' attitudes towards journalism as a career and to identify the obstacles to building a journalism career. This study employed the survey method with a questionnaire distributed among the female mass communication students of the Begum Rokeya University, Rangpur. From this research, it discovered that women have a negative attitude towards journalism as a career. Most female students do not want to build a journalism career because of family barriers, social or traditional outlook, extremist religious attitude, insecurity, physical limitation, discrimination between males and females at a media house, low salary, low evaluation of women, risk, and job environment.
\end{abstract}

Keywords: Attitude, Journalism, Career, Female Student.

DOI: $10.7176 / \mathrm{NMMC} / 95-03$

Publication date: January $31^{\text {st }} 2021$

\section{Introduction}

In the past, the journalism sector remains present and will be in the future. Women are an essential part like men in this profession of journalism (Ross, 2001). This study benefits female journalists because many people are puzzled over why women do not take up journalism as a career after studies. A journalist is the mirror of society through their reports and discourse of issues that span from diverse policy areas. According to BNSK 2006, the number of female journalists is increasing in Bangladesh, but their numbers are woefully low. There is fewer female at the policymaking level (Gassama et al.,2013). The study also focuses on female communication students' perception of journalism as a career and can know their career consideration obstacles. It may provide guidelines for women journalism students to practice journalism after completing their graduation. This study examines among the female mass communication students of Begum Rokeya University towards journalism as a career. Because of the discrepancies in women's enrolment in mass communication and journalism, the study aims to find out the attitudes of female students of Begum Rokeya University towards journalism as a career.

The following objectives cover this study:

-To find out the attitudes of female communication students of BRUR towards journalism as a career.

-What are the factors that are an obstacle to build a career in journalism?

\section{Statement of the problem:}

In Bangladesh, the number of female journalists in the field is very few. (Arul Aram ,2006) reported that news is still mainly reported and presented by men. Women journalists not often saw as lectures nor to women help develop and promote the professions (Remnek \& Ruane, 2001). This dormant attitude towards the profession has resulted in the male claiming superiority over them and not portraying women's right image in society. The study unveils the career consideration in journalism of female mass communication students of BRUR.

\section{Literature Review:}

Women comprise $12 \%$ of the workforce in journalism in India but only $40 \%$ of working journalists (Rajeev et al.,2019). Stereotyped attitudes, sexual harassment, traditional gender biases, and lack of support mechanism for working women deter women from joining the media(Cantalupo, 2019). Religious laws are privileged over constitutional guarantees, working against female journalists' interests (Safa \& Akter, 2015). Editors have said that they prefer to hire a man without a degree than a woman who has a journalism degree(Svensson \& Wang, 2013). During reporting dangerous events such as wars and conflict zones where a woman journalist, much like a male 
journalist, finds herself in a dangerous context(Sreberny, 2014). The audience in society still stands against gender equality. Women are often not aware of their rights; even females who depend on male protection are convinced that it is not in their best interests to claim those rights, says (Safa \& Akter, 2015). Women in Bangladesh media are still ruled by religious laws regarding legacy, marriage, divorce, and child custody(Zaman, 1999). In stories reported by women, $25 \%$ of news subjects are women than $20 \%$ of news subjects reported by men (Ross, 2007). The media are male-dominated in subject matter, news, and people who report news, prominence of male and female newsmakers and reporters(Baitinger, 2015).

A fair field and no favor must suffice for women in journalism(Freeman et al.,2011). Women journalists have to work twice as hard as male colleagues and always battle suggestions or perceptions that they are using sexuality to get ahead in their careers(Ross, 2001). They are more vulnerable than male colleagues to gossip, promotion prospects, and age factors for discrimination and miserably sexual harassment in the workplace increases (Ibrahim \& Spikin, 2020). In Eastern Africa, some media houses "violate female journalists' rights such as presenting them as sexual objects" and "sexual harassment, intimidation, abuse, undervaluing or ignoring their work, success, efforts, rights and by symbolically destroying or frustrating them" ( Canning et al.,2015).In Bangladesh, besides the killing of bloggers and numerous attacks on journalists, female journalists have also been specially targeted in the violence against the media by fundamentalist forces(Safa \& Akter, 2015). Most hidden and undocumented and female journalists who raise sexual harassment charges against colleagues or seniors are often at risk of losing their jobs, and their charges are either not taken up seriously or dismissed as false (Ibrahim \& Spikin, 2020). The above review of the literature indicates that there less involvement of women in the profession of journalism. Although many female journalists produced from different institutions offering mass communication, very few are involved in this profession.

\section{Material and Methods}

Methodology mainly indicates the strategy; model how or in which way a research work be completed. The survey method was used as a research design in this study. There are 89 female mass communication students in the Mass Communication and Journalism department at Begum Rokeya University, Rangpur, Bangladesh. Seventy female students were simple randomly selected from 89 female students to make up the sample size. The essence of using simple random sampling was to allow anyone in the population to be chosen or selected. The primary tool of this observational analysis is the questionnaire prepared for the survey. Data are pieces of information. Data identified as a collection of object-units that are distinct from one another. In this study, a self-administered structured questionnaire was used to collect the data from the research respondents.

The amount of students is almost seven thousand. Currently, the university twenty-one departments, and the amount of students is almost 7 thousand. It contains the student hall (including two males and one female). There are a library and a cafeteria on the campus. The university has constructed four academic buildings and started class in August 2011 on the main campus. Begum Rokeya University is a public university in the Rangpur Division, ranked second in the Rangpur division and 30th in national. Data interpretation allows the analysis of data and to determine or resolve the study query.SPSS version used for the data analysis with descriptive devices such as percentages and frequencies. Table and bar charts used for data presentation. The obtained data analyzed through the quantitative method. The data were categorized and analyzed using statistical tools and other arithmetic data analysis methods available viable. The study was published in the online edition of the scientific journal 'Data Processing.'

\section{Finding and Analysis}

Women's participation in newspapers in Bangladesh started in 1870 in this subcontinent(Safa \& Akter, 2015). Girls' participation in the current Bangladeshi newspapers as journalists, editors, reporters, writers, and scriptwriters are tremendous. Among 1500 reporters working in Dhaka -primarily based in Bangla and English newspapers, the range of women journalists had been 60 in 1996(Safa \& Akter, 2015). They should be diagnosed with the assistance of families rather than with character. The women in their lives experience gender dichotomy in any domain. They are glad about less of everything: meals, schooling, fitness care, etc. The woman was known to use a husband as the daughter of a father. This situation of women's Participation in newspapers is insignificant in quantity (Panday, 2010). Authors found that in this study, Bangladesh women experience gender duality in any domain. They would instead use their husband as a husband than as a person and want to have a husband who can provide all they need to get through the day. They also prefer to have someone to look after their children and to look out for them.

Furthermore, it is hard to find someone who can look after them properly. Besides, they are not wanted to be seen as a priority in the home and the community. Family is more important than their work, and they want to be looked after by caring for their children. They believe that their work is more important than their interests. The role of women in Bangladesh is to help their family and their community.

Women are devalued in terms of their gender identification in every aspect of the patriarchal social system in 
Bangladesh(Kabeer,2011); among more significant than 470 members of the countrywide Press membership, about 15 are women. Some females work at newspapers and information agencies in Dhaka and someplace else in the country. Given a choice, none of them but had opted to emerge as newshounds. They favored deskwork to report in journalism than in the field. A decade later, no female journalists remain in the profession. They go away to journalism as quickly as a higher job gives come and away again. The women work as sub-editors at desks or appearance after the newspapers' specialized feature. Some of them have their eyes on different jobs. Women's actual state of affairs newshounds inside the newspaper. One left journalism to be a banker. Any other took an airline process and by no means returned to journalism.

\subsection{Attitude Towards journalism:}

Women's enrolment and achievements at the educational establishments are improving in extraordinary dimensions. Many households are now encouraging their women to select journalism as a profession (Brems et al., 2017). Ekushey television CEO Manjurul Ahsan Bulbul stated that girl reporters are increasing notably in current days(Unb,2017). Women are doing highly nicely as journalists within the western media. Sexual harassment by using boss or colleagues is a commonplace factor in this quarter. Women face discrimination in professions' difficulty, face discrimination, and sexual harassment by boss or colleague is commonplace. Many universities or female college students have a poor attitude in the direction of journalism. They even concept that journalism is a volatile, insecure, and low profits profession. The number of women journalists has long passed up within the last couple of years, but our society, family, tradition, and women have a mindset towards journalism. Nowadays, many television channels are getting great for girls now, not the best news imparting and news reporting. The contribution of the television channel has modified our social norms and values approximately our female facet. Now the lady who is operating in news media is common in anywhere of our society with appreciation. Women journalists need to change their attitude toward journalism. Women journalists ought to comply with this direction and take journalism as their permanent profession. People who come to the career taste the excitement related to it, and they may live and inspire others to comply. Women should remember that almost 90 percent of us a's garment workers are a lady. Below are the data that the authors have complied with and analyzed by the primary investigation.

\section{Do you like journalism as a profession? To interpret these criteria:}

It has been observed that $68.57 \%$ of respondents believe that they have better journalism and think about journalism as a profession. On the other hand, $25.71 \%$ negative shows their approach on the journalism profession, $5.71 \%$ shown the undecided position.

What sector of journalism do you have an interest to work in: In the journalism segmentation issues, there categorically $14.04 \%$ like reporting section work, $40.35 \%$ like edition or desk work,5.26\% agreed on advertisement as their inclination choice, and $40.35 \%$ is on the presentation sector of the journalism?

How does someone look at journalism as a profession? In the above Table and Figure (table-03 and figure-03), above $45.59 \%$ of respondents believe that the journalism profession is a noble profession, $30.88 \%$ feel insecurity about that profession. $16.18 \%$ of respondents believe that they have the chance of discrimination; on the other hand, $1.47 \%$ and $5.88 \%$ of respondents believe that low salary profession and high salary profession about their approach setting.

We like reporting, although it is risky: it has been observed that $29.85 \%$ of respondents strongly believe that they agreed it has the risk, but they like reporting. $41.79 \%$ agreed as usual sense about their reporting issues of the journalism profession. $13.43 \%$ is the level of neutral about their reporting issues as considering the risk. On the other hand, $10.45 \%$ and $4.48 \%$ disagree and strongly disagree, respectively, in reporting as per the consideration risk issues of journalism.

We are interested in work editing or desk: It has been observed that $40.30 \%$ of the respondents strongly believe that they agreed they are interested in the desk or editing. $47.76 \%$ agreed as usual sense about their desk job liking issues of the journalism profession. $2.99 \%$ is the level of neutral about the interest issues of the desk job in journalism. On the other hand, $4.48 \%$ and $4.48 \%$ disagree and strongly disagree, respectively, in the case of a desk job due to the consideration of different journalism issues.

There is risk in the Journalism profession: it has been observed that $49.25 \%$ of respondents strongly believe that they agreed it has the risk. $43.28 \%$ agreed as usual sense risk level about the journalism profession. $4.48 \%$ is the level of neutral about considering it as a profession. On the other hand, $2.99 \%$ disagree in the case of considering risk at this profession.

Reporting is difficult to work or out in the field: it has been observed that $19.40 \%$ of respondents strongly believe that they agreed that reporting is problematic out of the field while $73.13 \%$ agree with this. $2.99 \%$ is the level of neutral about the reporting and difficulty level. On the other hand, $4.48 \%$ and $4.48 \%$ disagree that reporting is difficult to work or out in the field.

There is low participation of women in sports news coverage: it has been observed that $28.36 \%$ of respondents strongly believe that they agreed that there is love coverage in the sports news by female participation 
while $47.76 \%$ agree with this approach. $16.42 \%$ is the level of neutral about the female coverage of sports news; on the other hand, $2.99 \%$ and $4.48 \%$ disagree and strongly disagree, respectively, in low female sports news coverage in the journalism sector.

Translate work is comfortable in journalism: it has been observed that $23.88 \%$ of respondents strongly believe that $\mathrm{t}$ translate is comfortable in the journalism profession while $23.88 \%$ agree approach positively affect it. $25.37 \%$ is the level of neutral about translation is comfortable in the journalism profession. On the other hand, $25.37 \%$ and $1.49 \%$ disagree and strongly disagree, respectively. In translation, work is easy; they believe that it is a tough job in this profession.

Investigative Journalists have many sides to the foe. It has been observed that $49.25 \%$ of respondents strongly believe that the investigative journalist has many sides of the foe, while $43.28 \%$ strongly impact the positive support. $7.46 \%$ disagree in the case of investigative journals for both sides.

Women have low interest in coverage of political news: it has been observed that $31.34 \%$ of respondents strongly believe that women have low interest in the coverage of political news; on the other hand, $52.24 \%$ shown favorable agreement with this statement. $10.45 \%$ is the level of neutral about the female interest issues political news coverage. $5.97 \%$ disagree in the case of female interest in political news coverage.

Coverage of crime news is risky for women: it has been observed that $49.25 \%$ of respondents strongly believe that they agreed that crime news risky job while $40.30 \%$ agree with this and $10.45 \%$ here comparatively shown a neutral approach.

Women prefer the coverage of soft news like lifestyle, fashion, entertainment, etc. than hard news: it has been observed the $23.88 \%$ of respondents strongly believe that women like to cover soft news while $43.23 \%$ added more impact positively on this statement. $19.40 \%$ just shown the neutral figure. On the other hand, $2.99 \%$ and $10.45 \%$ disagree and strongly disagree, respectively, in soft news and hard news preferential area of a female. The literature-based scenario in perspective Bangladesh:

Women's participation in journalism is increasing globally, but they have no longer received much parity with their counterparts(Franks,2013). Stereotyped attitudes, traditional gender harassment, earnings differences, unfair treatment in assignments, and promotions are the main impediments. Females' reporters need to work twice as hard as male colleagues and should continuously war tips or perceptions that they are using sexuality to get ahead in their careers. Sexual harassment in media residence by using colleague or boss is one of the external issues. Extremist groups like Hefajat-e-Islam (a religion primarily based extremist organization) and their needs for banning the unfastened affiliation of men and women in public areas, media houses steer clear of sending women journalists to cowl their occasions. The pay-packet for an experienced journalist in Bangladesh is no extra than \$two hundred to \$300 a month - not a very attractive deal(Deutsche Welle,2019). It is most effective been within the past decade that Bangladesh females have begun to consider a career. Bangladesh's lifestyle is conservative, especially in its attitudes towards females' position within the home and society. Historically, our society's mindset has been that women want to meet their commitment to their own family first, so Bangladeshi females feel pressured to live domestically. Maximum control blames females' non-expert mindset as an excuse to create a barrier to management development.

\subsection{Obstacles factors}

Family Barrier: 29.03 percent suspect and 19.33 percent only believe there is a family barrier; it has been observed. 25.81 percent is the balanced interest standard. On the other hand, in the case of family hurdle concerns for not pursuing journalism as a profession, 11.29 percent and 14.52 percent oppose and strongly disagree, respectively. Traditional/social attitude: 19.35 percent of respondents firmly believe, and 37.10 percent believe a social attitude problem exists. 9.68 percent is the level of neutral interest. 9.68 percent is the level of neutral interest. On the other hand, for not preferring journalism as a career, 29.03 percent and 4.84 percent oppose and strongly disagree, respectively, on social mindset topics. Religious barrier: 29.03 percent of respondents have been found to believe firmly, and 30.65 percent believe that there is a religious barrier. 12.90 percent is the degree of neutral interest. On the other hand, in the case of religious barrier concerns for not selecting journalism as an occupation, 16.13 percent, and 11.29 percent oppose and strongly disagree, respectively. Insecurity: 33.87 percent of respondents strongly suspect, and 45.16 percent believe that insecurity remains. 16.13 percent is the degree of neutral interest. On the other hand, 1.61 percent and 3.23 percent oppose and firmly disagree, respectively, in vulnerability concerns for not preferring journalism as a career. Physical limitations: 16.13 percent of respondents suspect, and 45.16 percent believe physical limitations. The degree of neutral interest is 6.45 percent. On the other hand, in physical disabilities concerns for not preferring journalism as a profession, 22.58 percent and 9.68 percent oppose and 9.68 strongly disagree. Discrimination between male and female: it has been found that 25.81 percent of respondents strongly agree, and 54.84 percent only believe there is discrimination between male and female .1.61 percent is the degree of neutral interest. 17.13 percent, on the other hand, disagree with concerns of sexism for not preferring journalism as an occupation. It was found that 35.45 percent of respondents firmly agree that there is a low wage, and 54.84 percent believe that there is a low salary. 
The level of neutral interest represents 3.23 percent. On the other hand, for not preferring journalism as a career, 6.45 percent of low-wage problems. Low women's appraisal: 16.13 percent of respondents have been found to agree firmly, and 59.68 percent only believe that women's evaluation is low, 20.97 percent is the degree of neutral concern. On the other hand, in the case of weak assessment of women's problems, 3.23 percent deny that journalism is preferred as an occupation. Employment climate: 30.65 percent of respondents firmly believe, and 37.10 percent believe a job environment exists. The degree of favorable interest is 29.03 percent. On the other hand, 3.23 percent disagree with work climate concerns for not choosing journalism as a career. Risky: it has been found that 51.61 percent of respondents firmly believe and 43.55 percent only believe there is a risk, 4.84 percent is the degree of neutral concern regarding the troublesome issues for not choosing journalism as a profession.

\section{Synopsis}

Female mass communication students of Begum Rokeya University agree that journalism was a Nobel profession, but they have a negative attitude towards journalism as a career. Media house should employ women as presenters and assign them to the field as reporters. Women need to be provided with the correct training to enhance the skill of women in journalism. Working journalist salary should be increased to motivate and change the negative attitude, the study said. The results of the study were published in the journal Finding. The findings show that $75.81 \%$ of respondents believe in the journalism profession; females are not evaluating correctly.

\section{Conclusion:}

Bangladesh must create parallel opportunities for men and women to seek a career in either field. Nari Sangbadik Kendra (BNSK) was founded in Bangladesh on 13 March 2001 to support and encourage women who work for newspapers, electronic media, news, and online media companies. The number of female journalists is growing, but still not at the same level as the male journalists. The role of women in the journalism profession is to be fulfilled through education and skill training.

\section{References}

1. Agarwal, B., \& Bina, A. (1994). A field of one's own: Gender and land rights in South Asia (Vol. 58). Cambridge University Press.

2. ARAM, D. I. A. (2006). IMPACT OF FICTIONAL AND FACTUAL TELEVISION VIOLENCE ON CHILDREN. Children, Youth, and Electronic Media: Prospects and Portents, 25.

3. Baitinger, G. (2015). Meet the press or meet the men? Examining women's presence in American news media. Political Research Quarterly, 68(3), 579-592.

4. Bangladesh Nari Sramik Kendra (BNSK) - The Global Alliance Against Traffic in Women (GAATW). (2021). Retrieved 22 January 2021, from https://gaatw.org/members/asia/1027-bangladesh-nari-sramik-kendra-bnsk

5. Canning, D., Raja, S., \& Yazbeck, A. S. (Eds.). (2015). Africa's demographic transition: dividend or disaster? The World Bank.

6. Cantalupo, N. C. (2019). And even more of us are brave: intersectionality \& sexual harassment of women students of color. Harv. Women's LJ, 42, 1.

7. Franks, S. (2013). Women and journalism. Reuters Institute for the Study of Journalism.

8. Freeman, C. P., Bekoff, M., \& Bexell, S. M. (2011). Giving voice to the "voiceless" incorporating nonhuman animal perspectives as journalistic sources. Journalism Studies, 12(5), 590-607.

9. Gassama, I. J., Garoupa, N., \& Ginsburg, T. (2013). Global Studies Law Review. Washington University Global Studies Law Review, 12(4).

10. Kabeer, N. (2011). Between affiliation and autonomy: navigating pathways of women's empowerment and gender justice in rural Bangladesh. Development and change, 42(2), 499-528.

11. Panday, P. K. (2010). WOMEN JOURNALISTS IN THE PRINT MEDIA OF BANGLADESH AND THEIR PROFESSIONAL CHALLENGES. Women in Patriarchal Society, 132.

12. Ross, K. (2001). Women at work: Journalism as en-gendered practice. Journalism studies, 2(4), 531-544.

13. Ross, K. (2001). Women at work: Journalism as en-gendered practice. Journalism studies, 2(4), 531-544.

14. Ross, K. (2007). The journalist, the housewife, the citizen and the press: Women and men as sources in local news narratives. Journalism, 8(4), 449-473.

15. Safa, M. N., \& Akter, T. (2015). Challenges of female journalists in Bangladesh. Humanities and Social Sciences, 3(5), 207-214.

16. Sreberny, A. (2014). Violence against women journalists. Media and Gender: A Scholarly Alliance for the Global Alliance on Media and Gender, 35-39.

17. Svensson, M., \& Wang, H. (2013). Gendering Investigative Journalism. Chinese Investigative Journalists' Dreams: Autonomy, Agency, and Voice, 91.

18. Unb, D. (2017). Women in Journalism: Numbers on the rise yet hurdles remain. Retrieved 22 January 2021 , from https://www.thedailystar.net/city/numbers-the-rise-yet-hurdles-remain-1433239 
19. Zaman, H. (1999, January). Violence against women in Bangladesh: issues and responses. In Women's Studies International Forum (Vol. 22, No. 1, pp. 37-48). Pergamon.

20. (2021). Retrieved 22 January 2021, from https://www.dw.com/downloads/51296724/dwakademiejournalism-education-in-bangladesh.pdf 